\section{Identification of a population of mouse leukocytes using wheat germ agglutinin}

A GRoup of proteins occurring commonly in plant extracts have the property of agglutinating blood cells by intercellular linkage of surface carbohydrate groups ${ }^{1,2}$. These proteins, usually called lectins, are often able to distinguish cell types by preferentially agglutinating cells which express a particular membrane glycoprotein ${ }^{3}$. We report here that one lectin, wheat germ agglutinin (WGA) ${ }^{4}$, is able to distinguish a group of mouse leukocytes carrying neither immunoglobulin nor T-cell surface markers.

Cells teased from spleens of normal $\mathrm{BALB} / \mathrm{c}$ mice were washed with Eagle's minimum essential medium containing $10 \%$ foetal bovine serum. Suspensions containing $10^{7}$ cells $\mathrm{ml}^{-1}$ were treated with increasing concentrations of fluoresceinconjugated WGA and the number of labelled cells counted immediately using a Leitz Ortholux ultraviolet microscope with incident illumination. The results are shown in Fig 1. A consistent proportion of spleen cells was found to be strongly labelled at WGA concentrations of between 20 and $100 \mu \mathrm{g} \mathrm{ml}^{-1}$. Staining was eliminated either by previous addition of $0.025 \mathrm{M}$ $\mathrm{N}$-acetyl glucosamine (NAG) to the cell suspension, or by subsequent washing of the cells with Eagle's medium containing $0.05 \mathrm{M}$ NAG. In contrast, washing with $0.1 \mathrm{M}$ NAG had no effect upon spleen cells previously labelled with another fluorescein-conjugated lectin, concanavalin A.

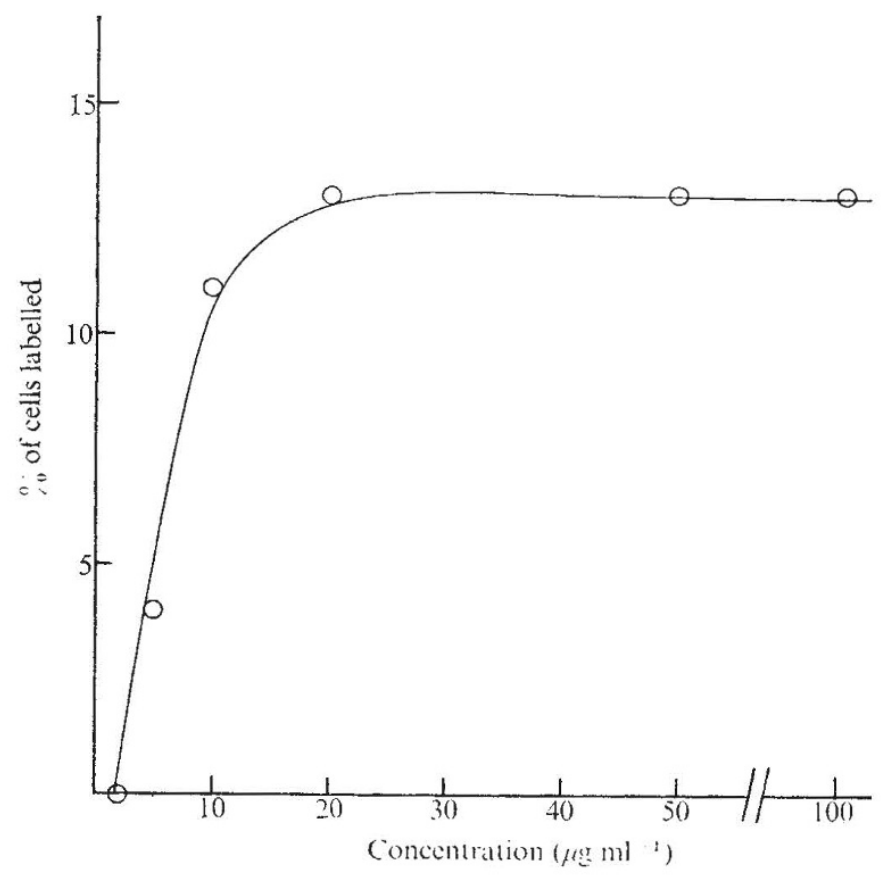

Fig. 1 Proportion of mouse spleen cells labelled with increasing concentrations of fluorescein-conjugated WGA.

Table 1 shows the proportions of cells from other mouse lymphatic tissues having receptors for WGA.

The morphology of this cell population was investigated by electron microscopy. Mouse spleen cells were incubated for $5 \mathrm{~min}$ at $4^{\circ} \mathrm{C}$ with a $250 \mu \mathrm{g} \mathrm{ml}^{-1}$ concentration of WGA/ horseradish peroxidase conjugate ${ }^{5}$ in phosphate buffered saline. The cells were then washed, fixed and treated with diaminobenzidine and osmium tetroxide before embedding and sectioning. Cells with heavy surface labelling were characterised as monocytes and polymorphonuclears, many with peroxidasepositive cytoplasmic granules. Lymphocytes and plasma cells showed very weak or no staining. Further details of these experiments will be published elsewhere.
To see whether cells with abundant WGA receptors carried immunoglobulin or T-cell markers the following experiment was performed. Aliquots of $2 \times 10^{6}$ cells were treated with either $100 \mu \mathrm{l}$ of a $1: 4$ dilution of rabbit anti-mouse immunoglobulin serum or with $100 \mu \mathrm{l}$ of rabbit anti-mouse brain serum, sequentially absorbed with erythrocytes, liver and B-spleen (spleen from irradiated animals repopulated with bone marrow cells) to render it specific for T lymphocytes ${ }^{6}$. All cells were subsequently

Table 1 Percentage of leukncytes in mouse tissues labelled with WGA $\left(50 \mu \mathrm{g} \mathrm{m} l^{-1}\right)$

\begin{tabular}{|c|c|c|c|c|}
\hline $\begin{array}{l}\text { Spleen } \\
12\end{array}$ & $\begin{array}{l}\text { Lymph node } \\
<0.5\end{array}$ & $\begin{array}{c}\text { Thymus } \\
<0.5\end{array}$ & $\begin{array}{c}\text { Blood } \\
7\end{array}$ & Bone marrow \\
\hline
\end{tabular}

stained with rhodamine B-conjugated goat anti-rabbit immunoglobulin serum. The cells were then washed thrice and labelled with $100 \mu \mathrm{l}$ of a $50 \mu \mathrm{g} \mathrm{ml}^{-1}$ solution of fluorescein-conjugated WGA. Of the $12 \%$ of cells in each sample labelled with wheat germ agglutinin, none showed rhodamine fluorescence indicative of either immunoglobulin or T-cell surface markers. Conversely, T cells were not stained with WGA. Although WGA did not stain immunoglobulin-bearing cells under these conditions, at lectin concentrations greater than $100 \mu \mathrm{g} \mathrm{ml}^{-1}$, both immunoglobulin-bearing cells and erythrocytes showed weak fluorescence.

This is consistent with the findings of Schnebli and Dukor that mouse $B$ cells are agglutinated more strongly than cortisoneresistant thymocytes at low concentrations of WGA. Wheat germ agglutinin has also been shown to agglutinate certain malignant cells ${ }^{8}$. Our results show that mouse leukocytes in lymphoid organs and blood which have abundant binding sites for WGA are essentially of myeloid morphology and do not carry the surface markers of B or T lymphocytes.

We thank Dr A. K. Allen for his gift of purified WGA, Dr C. Maino for a number of other lectins used in this study and Miss M. Gyöngyössy for rabbit anti-mouse brain serum. This work was supported by the Medical Research Council.

Note added in proof: In contrast wfth resting mouse lymphocytes, lymph node cells transformed with phytohaemagglutinin or concanavalin $\mathrm{A}$ were found to bind WGA to a moderate degree.

\section{P. J. ROBINSON}

I. M. RoITt

Department of Immunology,

Middlesex Hospital Medical School,

London WIP 9PG, UK

Received April 22; revised June 19, 1974.

1 Mäkelä, O., Annls Med, exp. Biol. Fenn., 35, Suppl. 11 (1957).

${ }^{2}$ Lis, H., and Sharon, N., A. Rev. Biochem., 42, $541-574$ (1973).

3 Blumberg, S., Hildesheim, J., Yariv, J., and Wilson, K. J., Biochem. biophys. Acta., 264, 171-176 (1972).

${ }^{4}$ Allen, A. K., Neuberger, A., and Sharon, N., Biochem. J., 131, $155-162$ (1973).

${ }^{5}$ Huet, C., and Garrido, J., Expl Cell Re's., 75, 523-527 (1972).

${ }^{6}$ Gyöngyössy, M. I. C., and Playfair, J. H. L., Cell. Immun., 7, 118-123 (1973).

${ }^{7}$ Schnebli, H. P., and Dukor, P., Eur. J. Immun., 2, 607-609 (1972).

${ }^{8}$ Burger, M. M., and Goldberg, A. R., Proc. natn. Acad. Sci. U.S.A., 57, 359-366 (1967).

\section{Adjuvant activity in delayed hypersensitivity of the peptidic part of bacterial peptidoglycans}

IT is generally accepted that the presence of killed mycobacteria in complete Freund's adjuvant is necessary to induce a typical delayed hypersensitivity to soluble antigens ${ }^{1}$ and attempts have been made to isolate the active component. The preparations obtained initially were of a peptidogly- 